\title{
Built and social environments and overweight among Brazilian adults from medium-sized city: CUME Project
}

\author{
Ambientes construído e social e excesso de peso em adultos \\ brasileiros de uma cidade de médio porte: Projeto CUME
}

Ana Luiza Gomes Domingos (https://orcid.org/0000-0001-7010-0574) ${ }^{1}$

Helen Hermana Miranda Hermsdorff (https://orcid.org/0000-0002-4441-6572) ${ }^{1}$

Larissa Loures Mendes (https://orcid.org/0000-0003-0776-6845) ${ }^{2}$

Fernando Luiz Pereira de Oliveira (https://orcid.org/0000-0001-6513-3339) ${ }^{3}$

Anderson Castro Soares de Oliveira (https://orcid.org/0000-0001-6222-9300) ${ }^{3}$

Adriano Marçal Pimenta (https://orcid.org/0000-0001-7049-7575) ${ }^{4}$

Josefina Bressan (https://orcid.org/0000-0002-4993-9436) ${ }^{1}$
${ }^{1}$ Departamento de Nutrição e Saúde, Universidade Federal de Viçosa. Campus Universitário, s/n. 36570900 Viçosa MG Brasil. algdomingos@gmail.com ${ }^{2}$ Departamento de Nutrição, Escola de Enfermagem, Universidade Federal de Minas Gerais. Belo Horizonte MG Brasil. ${ }^{3}$ Departamento de Estatística, Universidade Federal de Ouro Preto. Ouro Preto MG Brasil.

${ }^{4}$ Departamento de Enfermagem MaternoInfantil e Saúde Pública, Escola de Enfermagem, Universidade Federal de Minas Gerais. Belo Horizonte MG Brasil.

\begin{abstract}
A cross-sectional study enrolled participants from the CUME project $(n=289)$ who lived in Viçosa, Brazil. The neighborhood unit adopted was the buffer (200 meters), considering the participant's residence as central point. We measure the number of public and private facilities inside the buffer as well as violent criminal occurrences. Food establishments were categorized into establishments with predominant sale of natural or minimally processed foods, mixed establishments, and establishments with predominant sale of ultra-processed foods. Those who attended the faceto-face interview filled two scales of perception of the environment. Overall, $33.6 \%$ of participants reported overweight. We observed a higher concentration of individuals close to the central region of the city. Access to different establishments, food environments, and criminal occurrences differed between normal-weight and overweight individuals. The groups deferred in the perception of the location of squares, open public spaces, clubs, and soccer fields. The results indicate the association between environmental characteristics and overweight in Brazilian adults.

Key words Built environment, Food environment, Geographic information systems, Overweight, Social environment
\end{abstract}

Resumo Realizou-se um estudo transversal com participantes do projeto CUME $(n=289)$ que moravam em Viçosa, Brasil. A unidade de vizinhança adotada foi o buffer (200 metros), considerando a residência do participante como ponto central. Foi contabilizado o número de instalações públicas e privadas dentro do buffer, bem como as ocorrências criminais. Os estabelecimentos alimentares foram categorizados em estabelecimentos com venda predominante de alimentos naturais ou minimamente processados, estabelecimentos mistos e estabelecimentos com venda predominante de alimentos ultraprocessados. Os participantes que compareceram à entrevista presencial, preencheram duas escalas de percepção do ambiente. No total, 33,6\% dos participantes apresentaram excesso de peso. Foi observada uma maior concentração de indivíduos próximos à região central da cidade. $O$ acesso a diferentes estabelecimentos, ambientes alimentares e ocorrências criminais diferiram entre indivíduos com eutrofia e com excesso de peso. Os grupos diferiram na percepção da localização de praças, espaços públicos abertos, clubes e campos de futebol. Os resultados indicam a associação entre as características ambientais e o excesso de peso em adultos brasileiros.

Palavras-chave Ambiente construído, Ambiente alimentar, Sistemas de informação geográfica, Sobrepeso, Meio social 


\section{Introduction}

Overweight is a growing public health problem affecting an increasing number of countries worldwide. Today, the majority of the world's population lives in countries where overweight and obesity kill more than malnutrition. Since 1975, world prevalence has tripled. By 2016, more than 1.9 billion (39\%) adults were overweight, with 650 million (13\%) of them obese. The projection is that, by 2025 , about 2.3 billion adults will be overweight; and more than 700 million, obese ${ }^{1}$.

The magnitude of the problem is astonishing. In the Brazilian adult population, 54\% fit this description ${ }^{2}$. Both overweight and obesity are known to be significantly associated with a range of chronic conditions such as cardiovascular disease, type 2 diabetes, musculoskeletal problems, chronic kidney disease, cancer, and fair or poor health status ${ }^{3-5}$. From an economic point of view, overweight impacts directly or indirectly on the overload of the health system in both the public and private spheres, on the reduction of quality of life and on premature death ${ }^{6,7}$.

In trying to develop an understanding of the causes of obesity, the influence of the environment is currently in public health research. The obesogenic environment is defined as the sum of forces that the surroundings, opportunities, or conditions of life have on promoting obesity in individuals or populations 8 .

In the study of the built environment, the geographic distribution of public and private spaces that favor the practice of physical activity is investigated, as well as the presence and conservation of streets and sidewalks, connectivity between streets, land use and also the aesthetic quality of the neighborhood (e.g. green areas, cleaning and pollution) $)^{9}$.

The food environment, component of the built environment, considers, among other aspects, the geographic location of supermarkets, grocery stores, bars and snack bars, restaurants, as well as the presence or absence of establishments that market healthy food ${ }^{10-12}$. Adopting a healthy and varied diet becomes easier if the food market in the neighborhood allows it, providing healthy food at affordable prices ${ }^{10,12}$. A study conducted in Canada identified that the lower the proportion of fast-food restaurants/convenience stores and grocery stores/producers near the participants' homes, the lower the chance of being obese ${ }^{13}$.

In a similar perspective, the social environment includes elements related to living condi- tions, income and educational levels in the area, public safety, social support networks and level of trust, which are associated with greater or lesser disorder and social deprivation in the region in which the individual is located. Regarding public safety, adults who perceived their neighborhoods as unsafe had a higher body mass index than those who considered it a safe place. In these locations, the presence of pedestrians in the public space can stimulate personal and social interactions, thus favoring the practice of physical activity, such as hiking, running groups and outdoor sports ${ }^{14}$. Furthermore, a study conducted with Hispanic-American adults in the United States identified that meeting physical activity recommendations was associated with the presence of sidewalks and inversely related to higher criminal activity $^{15}$.

In Brazil, few published studies have simultaneously assessed the geographic distribution of the social and built environments, allied to the individual's perception of this space and his lifestyle. Additionally, the study of the obesogenic environment in Brazil is limited, especially in medium-sized cities. Therefore, the present study evaluated the association between environmental and individual characteristics and overweight among adult participants of the Cohort of Universities of Minas Gerais (CUME project) from a median-sized city.

\section{Materials and methods}

\section{Study design and population}

The Cohort of Universities of Minas Gerais (CUME project) is a Brazilian, dynamic, multi-purpose, and prospective cohort study with university graduates. Information on exposure and outcome is gathered by mailed questionnaires collected biennially since 2016. Details of its design have been published elsewhere ${ }^{16}$.

For this study, our sample was restricted to those who participated in the CUME project and lived in Viçosa, during $2016(\mathrm{n}=315)$. We excluded from the current analysis of pregnant women $(\mathrm{n}=13)$ and those living abroad in the last year $(n=13)$. To complete the perception questionnaire, all participants living in Viçosa were invited to attend the Laboratory of Energy Metabolism and Body Composition at the Federal University of Viçosa. 


\section{Ethical aspects}

The project "Cohort of Universities of Minas Gerais (CUME project): Impact of the Brazilian food pattern and nutritional transition on non-communicable diseases and illnesses" is in accordance with the ethical principles of non-maleficence, beneficence, justice and autonomy ${ }^{17}$. This research was conducted in accordance with the ethical principles stated in the Declaration of Helsinki, and was approved by the Human Research Ethics Committees of the UFV and the UFMG (Protocol No. 1,939,752 and 596,741-0).

\section{Study region}

The study was conducted in the urban area of Viçosa, a medium-sized city, with 72,220 inhabitants, a territory of $299 \mathrm{~km}^{2}$ and a population density of 241.20 inhabitants $/ \mathrm{km}^{218}$. Viçosa is located in Minas Gerais, $221.6 \mathrm{~km}$ from the capital of the state, Belo Horizonte. This city is fundamentally oriented to education, with emphasis on the Federal University of Viçosa, founded in 1926. Ever since, Viçosa experienced rapid urban growth with the emergence of densification and verticalization of the center near the university, mainly occupied by students ${ }^{19}$.

\section{Outcome assessment}

The primary outcome variable of this study was an overweight occurrence. For this, Body Mass Index (BMI) was calculated using validated self-reported weight and height ${ }^{20}$, and participants with a BMI $\geq 25.0 \mathrm{~kg} / \mathrm{m}^{2}$ were defined as overweight $^{21}$.

\section{Covariates}

The questionnaire included questions about a wide array of characteristics: socio-demographic (sex, age, marital status, college degree, employment, individual income, household size), lifestyle and health-related habits (binge drinking and physical activity), self-reported health status and family history of obesity.

Binge drinking was defined as five or more alcoholic drinks for males or four or more alcoholic drinks for females on the same occasion on at least one day in the past month ${ }^{22}$. Physical activity was investigated utilizing a list of leisure activities and the time/frequency spent on them $^{23}$. Individuals with $\geq 150$ minutes/week of moderate-intensity activity or $\geq 75$ minutes/ week of vigorous-intensity activity were considered active ${ }^{24}$.

\section{Built environment}

The neighborhood unit used to evaluate the environment was the buffer of 200 meters, considering the participant's residence as a central point. The buffer size was chosen from a

literature review, which indicates that this distance corresponds to a five-minute walk ${ }^{25,26}$.

The names and addresses of the establishments were provided by the Sanitary Surveillance Service of the Municipality of Viçosa. Besides, those establishments no registered in the database were georeferenced and after registered. The georeferencing was performed through the application ColetAPP Version 1.0, idealized by the Department of Informatics of the Federal University of Viçosa ${ }^{27}$. The data were collected in the configuration of the WGS 84 Geographic Coordinate System and later transformed into the System of Coordinates Coordinated, Universal Transverse Mercator System (UTM), 23S, SIRGAS 2000 datum, through the software QGIS 3.4.2.

To assess the built environment, the following types of establishments were registered: clubs, outdoor gyms, gymnastic academies, pilates and yoga studios, martial arts and dance academies; bank branches, churches, and religious temples; hospitals and primary health units.

Food establishments were categorized into establishments with predominant sale of natural or minimally processed foods (farmers market, greengrocery, butchery, and fish market), mixed establishments (bakeries, bars, restaurants, places that sell products in bulk, and dairy products, supermarkets), and establishments with predominant sale of ultra processed foods (cafeterias, confectionery, ice cream parlors, temporary street food stands, grocery store, and convenience stores $)^{28}$.

\section{Police-recorded crime}

Police-recorded crime data (2015-2016) were obtained from the Police Civil of the State of Minas Gerais, including crime location geocoded, date, and crime type. Crime types were categorized and mapped as crimes against sexual dignity (sexual harassment, obscene act, and rape), property crimes (theft and robbery) and crimes against persons (homicide, kidnapping, burglary), according to the Brazilian Penal Code ${ }^{29}$. 


\section{Perceived environmental attributes}

For the analysis of the environment perception, only those participants who reported living in the address for at least the last six months were included. The Scale of Perception of the Environment for the Practice of Physical Activity was adapted and validated for a Brazilian population. The instrument was composed of 38 questions about the built environment/environmental structures for the physical activity, sidewalks, green areas, street topography, environmental pollution, traffic safety, general safety, social support, climate and domestic pet (e.g., dogs). The alternatives of were standardized in dichotomies $(\text { yes or no })^{30}$.

The first part of the scale was composed of a list of 18 locations and the walking time between the participant's residence and the respective position within the neighborhood. Participants were advised to consider as "near their residences" locations that could reach within ten minutes by walking. With this information, the general accessibility score was elaborated based on the median value $(\mathrm{p} 50)^{30}$.

The second scale was translated, adapted and validated by researchers from the multi-center ELSA-Brazil cohort (Longitudinal Study of Adult Health), based on the following studies: Project on Human Development in Chicago Neighborhoods $(\mathrm{PHDCN})^{31}$ and Multi-Ethnic Study of Atherosclerosis (MESA) ${ }^{32}$. The scale covers five domains: social cohesion, walking environment, availability of healthy foods, safety, perceived violence and personal victimization ${ }^{33}$.

The Likert psychometric response scale containing five points (I fully agree, partially agree, do not agree or disagree, partially disagree, totally disagree). Cards with each answer option were drawn up and presented together to the participants. For analytical purposes, the following questions were coded in reverse: People in this neighborhood generally don't get along with each other; People in this neighborhood do not share the same values; My neighborhood has heavy traffic; There are many busy roads to cross when out for walks in my neighborhood; Violence is a problem in my neighborhood ${ }^{33}$. After the reverse coding, social cohesion, walking environment, availability of healthy foods, safety, were constructed based on the median value (p50). Perceived violence was assessed by frequency (often, rarely, never) with which participant reported fights that involved the use of weapons in the neighborhood, violent discussion among neighbors, gang fighting, sexual violence or rape, robbery, or assault ${ }^{33}$.

\section{Statistical analyses}

QGIS version 2.18 was used to map and calculate the household's accessibility to establishments and criminal occurrences within the 200 meters buffer (Euclidean distance). Means and standard deviations were calculated for continuous variables, and frequency distributions were calculated for categorical variables. Statistical differences were evaluated with the chi-square Pearson test $\left(\chi^{2}\right)$. Differences between two independent groups were assessed by Student's t-test and Mann Whitney test, according to the normality of the variables, which in turn was verified by the Shapiro-Wilk test. All analyses were conducted with Stata Software (version 13.0), with a significance level of $5 \%$.

\section{Results}

We analyzed information from 289 respondents, from which $33.6 \%$ were overweight. Among participants, $75.4 \%$ had concluded some postgraduate study, $66.1 \%$ were females, $41.2 \%$ aged between 20 and 29 years, and $71.7 \%$ earned less than five times the minimum wage. Significant differences were found between normal weight and overweight groups concerning sex, age, and self-reported health status (Table 1).

Concerning to the spatial distribution, we found a concentration of participants living in the central region of the city, close to the university. Table 2 shows the spatial accessibility to establishments and criminal occurrences within the 200-meter buffer.

The overweight group has less total availability to establishments such as commercial physical activity-related establishments (Figure 1), bakeries and butcher shops. In relation to the social environment, it was observed that individuals who were overweight were less exposed to total criminal occurrences more specifically to crimes against property (Table 2 ).

All participants who reported living in the city were invited to attend a face-to-face interview; 138 of them (27.5\%, overweight) agreed to participate. Differences were found between the groups about the perception of the location of squares $(p=0.038)$ places for a walk $(p=0.021)$, open public spaces $(\mathrm{p}=0.008)$, clubs $(\mathrm{p}=0.040)$ and soccer field $(\mathrm{p}=0.008)$. No different sta- 
Table 1. Sample characterization, according to weight status. Cohort of Universities of Minas Gerais (CUME project).

\begin{tabular}{|c|c|c|c|c|}
\hline Characteristic & $\begin{array}{c}\text { Normal } \\
\text { weight } \\
\text { n }(\%)\end{array}$ & $\begin{array}{c}\text { Overweight } \\
\text { n (\%) }\end{array}$ & $\begin{array}{l}\text { Total } \\
\mathbf{n}(\%)\end{array}$ & p-value \\
\hline $\operatorname{Sex}(n=289)$ & & & & $<0.001$ \\
\hline Female & $147(76.6)$ & $44(45.4)$ & $191(66.1)$ & \\
\hline Male & $45(23.4)$ & $53(54.6)$ & $98(33.9)$ & \\
\hline Age, years $(n=289)$ & & & & $<0.001$ \\
\hline $20-29$ & $92(47.9)$ & $27(27.8)$ & $119(41.2)$ & \\
\hline $30-39$ & $76(39.6)$ & $40(41.2)$ & $116(40.1)$ & \\
\hline $40-49$ & $20(10.4)$ & $25(25.8)$ & $45(15.6)$ & \\
\hline $50-65$ & $4(2.1)$ & $5(5.2)$ & $9(3.1)$ & \\
\hline Individual income ${ }^{\mathrm{a}}$, times the minimum wage $(\mathrm{n}=212)$ & & & & 0.127 \\
\hline$<5$ & $108(76.1)$ & $44(62.9)$ & $152(71.7)$ & \\
\hline$\geq 5$ to $<10$ & $25(17.6)$ & $20(28.6)$ & $45(21.2)$ & \\
\hline$\geq 10$ & $9(6.3)$ & $6(8.6)$ & $15(7.1)$ & \\
\hline Marital status $(\mathrm{n}=289)$ & & & & 0.127 \\
\hline Legally married/Stable union/Other & $75(39.1)$ & $47(48.5)$ & $122(42.2)$ & \\
\hline Single/Separated/Divorced & $117(60.9)$ & $50(51.5)$ & $167(57.8)$ & \\
\hline Household size $(\mathrm{n}=289)$ & & & & 0.749 \\
\hline 1 person & $31(16.1)$ & $15(15.5)$ & $46(15.9)$ & \\
\hline 2-4 people & $148(77.1)$ & $73(75.3)$ & $221(76.5)$ & \\
\hline$\geq 5$ people & $13(6.8)$ & $9(9.3)$ & $22(7.6)$ & \\
\hline Level of education $(\mathrm{n}=289)$ & & & & 0.888 \\
\hline Bachelor's degree & $49(25.5)$ & $22(22.7)$ & $71(24.6)$ & \\
\hline Specialization degree & $19(9.9)$ & $8(8.2)$ & $27(9.3)$ & \\
\hline Master’s degree & $85(44.3)$ & $45(46.4)$ & $130(45.0)$ & \\
\hline Doctorate/post-doctorate & $39(20.3)$ & $22(22.7)$ & $61(21.1)$ & \\
\hline Professional situation $(\mathrm{n}=289)$ & & & & 0.113 \\
\hline Full time/part time/informal & $94(49.0)$ & $59(60.8)$ & $153(52.9)$ & \\
\hline Student & $90(46.9)$ & $33(34.0)$ & $123(42.6)$ & \\
\hline Retired/unemployed & $8(4.2)$ & $5(5.2)$ & $13(4.5)$ & \\
\hline Smoking habit $(\mathrm{n}=288)$ & & & & 0.110 \\
\hline Current smoker & $12(6.3)$ & $13(13.5)$ & $25(8.7)$ & \\
\hline Binge drinking $(\mathrm{n}=288)$ & & & & 0.156 \\
\hline Yes & $87(45.3)$ & $52(54.2)$ & $139(48.3)$ & \\
\hline Self-reported health status $(n=266)$ & & & & $<0.001$ \\
\hline Very good/good & $167(94.4)$ & $70(78.7)$ & $237(89.1)$ & \\
\hline Physical activity $(\mathrm{n}=288)$ & & & & 0.932 \\
\hline Active & $117(60.9)$ & $59(61.5)$ & $176(61.1)$ & \\
\hline Family history of obesity $(n=266)$ & & & & 0.536 \\
\hline Yes & $55(31.1)$ & $31(34.8)$ & $86(32.3)$ & \\
\hline
\end{tabular}

${ }^{\mathrm{a}}$ Minimum wage (R\$ 880.00 in 2016). p-values from Pearson chi-squared test.

Source: Authors.

tistics were found in the analysis of perception scores (Table 3).

\section{Discussion}

The present study identified the relationship between environmental characteristics and the prevalence of overweight among highly educat- 
Table 2. Spatial accessibility to establishments and criminal occurrences within the 200-meter buffer, according to weight-status. Cohort of Universities of Minas Gerais (CUME project).

\begin{tabular}{|c|c|c|c|c|}
\hline & $\begin{array}{c}\text { Normal weight } \\
\quad(n=192)\end{array}$ & $\begin{array}{l}\text { Overweight } \\
\quad(\mathbf{n}=\mathbf{9 7})\end{array}$ & $\begin{array}{c}\text { Total } \\
(\mathrm{n}=289)\end{array}$ & p-value \\
\hline & Mean \pm SD & Mean \pm SD & Mean \pm SD & \\
\hline Gyms/studios & $1.80 \pm 1.74$ & $1.20 \pm 1.42$ & $1.60 \pm 1.67$ & 0.002 \\
\hline Bank branches & $0.31 \pm 0.93$ & $0.21 \pm 0.82$ & $0.27 \pm 0.90$ & 0.368 \\
\hline Clubs & $0.20 \pm 0.49$ & $0.33 \pm 0.64$ & $0.24 \pm 0.55$ & 0.077 \\
\hline Total commercial physical activity Establishments & $2.0 \pm 1.84$ & $1.53 \pm 1.56$ & $1.84 \pm 1.76$ & 0.031 \\
\hline Churches and religious temples & $1.27 \pm 1.27$ & $1.19 \pm 1.40$ & $1.24 \pm 1.31$ & 0.605 \\
\hline Hospitals and primary health units & $0.27 \pm 0.58$ & $0.33 \pm 0.59$ & $0.29 \pm 0.58$ & 0.421 \\
\hline Ice cream parlors & $1.26 \pm 2.23$ & $0.74 \pm 1.78$ & $1.09 \pm 2.10$ & 0.003 \\
\hline Farmers market & $0.10 \pm 0.34$ & $0.05 \pm 0.22$ & $0.08 \pm 0.31$ & 0.161 \\
\hline Places that sell products in bulk and dairy products & $0.42 \pm 0.84$ & $0.29 \pm 0.81$ & $0.38 \pm 0.83$ & 0.202 \\
\hline Greengrocery & $0.56 \pm 0.84$ & $0.40 \pm 0.64$ & $0.51 \pm 0.78$ & 0.160 \\
\hline Supermarkets & $0.46 \pm 0.94$ & $0.31 \pm 0.82$ & $0.41 \pm 0.90$ & 0.167 \\
\hline Bakeries & $1.17 \pm 1.57$ & $0.74 \pm 1.14$ & $1.02 \pm 1.45$ & 0.010 \\
\hline Grocery store & $1.57 \pm 1.55$ & $1.52 \pm 1.69$ & $1.55 \pm 1.60$ & 0.794 \\
\hline Butchery and fish market & $1.58 \pm 2.25$ & $1.04 \pm 1.79$ & $1.40 \pm 2.12$ & 0.029 \\
\hline Bars and Restaurants & $11.31 \pm 13.91$ & $7.14 \pm 10.69$ & $9.91 \pm 13.05$ & 0.005 \\
\hline Total food establishments & $22.27 \pm 22.97$ & $15.48 \pm 18.23$ & $19.99 \pm 21.70$ & 0.007 \\
\hline \multicolumn{5}{|l|}{ Food establishments by category } \\
\hline Natural or minimally processed & $2.23 \pm 2.87$ & $1.49 \pm 2.25$ & $1.98 \pm 2.70$ & 0.017 \\
\hline Mixed & $7.65 \pm 8.25$ & $5.05 \pm 6.37$ & $6.78 \pm 7.76$ & 0.003 \\
\hline Ultra-processed & $8.73 \pm 10.99$ & $5.93 \pm 8.95$ & $7.79 \pm 10.42$ & 0.021 \\
\hline Total criminal occurrences & $55.99 \pm 54.90$ & $40.0 \pm 45.91$ & $50.66 \pm 52.52$ & 0.010 \\
\hline Crimes against sexual dignity & $0.29 \pm 0.57$ & $0.23 \pm 0.49$ & $0.27 \pm 0.54$ & 0.344 \\
\hline Crimes against people & $0.53 \pm 0.88$ & $0.60 \pm 1.05$ & $0.55 \pm 0.94$ & 0.571 \\
\hline Property crimes & $11.06 \pm 9.56$ & $8.38 \pm 8,57$ & $10.16 \pm 9.31$ & 0.021 \\
\hline
\end{tabular}

Source: Authors.

ed Brazilian adult residents in a medium-sized city. The evaluation of the environment in Viçosa emerged from the need for studies that aim to evaluate the social and built environment, as well as the physical and perceived environment.

When considering the geographical distribution of the participants' residence, a concentration was identified in the downtown area, a fact that is justified due to the historical impact of the university in the urban configuration of Viçosa. Nowadays, the intensification of spatial segregation in the city can be observed as well as the downtown and surroundings being occupied by people connected to the university, and the less favored population were eventually excluded and displaced to the peripheral regions of the city ${ }^{34,35}$.

Regarding individual characteristics, we identified differences between groups (normal-weight vs. overweight) in relation to sex, age, and self-reported health status. Self-reported health status is a valid and relevant indicator of the health status of individuals. It is strongly related to objective measures of morbidity, the use of services, and an important predictor of mortality $^{36}$.

In Brazil, 2.6\% of the people evaluated their health status negatively, being this proportion higher in women $(3.5 \%)$ than in men $(1.3 \%)$. The frequency of this condition in both sexes decreased with the increase of education level ${ }^{37}$. However, in our study, we identified the prevalence of dissatisfaction higher (10.9\% vs. $2.6 \%)$ than the national average, even in individuals with a high educational level.

When evaluating the objective environment and the access to the facilities, we identified that the overweight individuals have fewer facilities within the 200 meters buffer around the residence than the normal-weight group. The same pattern was observed concerning the geolocation 

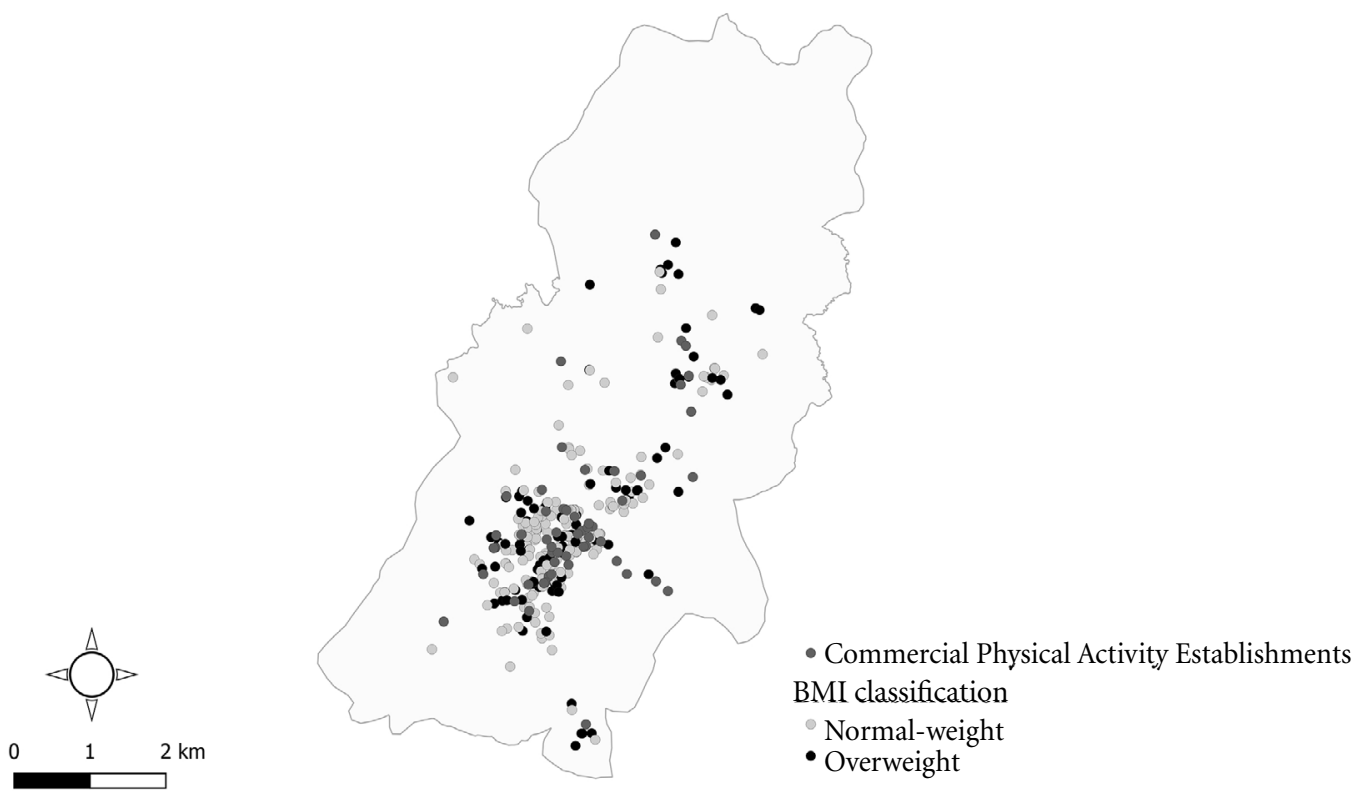

Figure 1. Spatial distribution of residential addresses of the study population and commercial establishments for physical activity in Viçosa, Minas Gerais, 2016.

Source: Authors.

of criminal occurrences and the food environment. This result may have been influenced by the clustering of residents and establishments in the city centre.

A previous study in the city of Viçosa identified that out of a total of 656 food establishments located in the city, $11.1 \%$ had predominant sale of natural or minimally processed foods, $44.5 \%$ were mixed, and $44.4 \%$ had predominant sale of ultra-processed foods, and were clustered in central and higher income regions of the city ${ }^{38}$.

Likewise, a study conducted in Jundiaí, a medium-sized Brazilian city, identified an unequal geographical distribution of retail food stores. The authors reported that the central region of the city accommodated a greater concentration of food establishments, street market, meat shops and producer direct street markets $\mathrm{s}^{39}$.

In Brazil, studies such as that conducted by Jaime et al. (2011) have sought to understand the influence of the environment and health outcomes as overweight. In their study of the city of São Paulo, the authors pointed out a relevant spatial variation in the patterns of diet, physical activity, built and food environments and a more favorable scenario in the wealthiest $\operatorname{areas}^{40}$.
Besides the spatial distribution of the environments, it is also important to evaluate the individual's perception of that particular space and how these two factors influence a food intake pattern and the physical activity practice. As an example, city residents of São Paulo considered their neighborhoods to be favorable to the consumption of ultra-processed foods and reported more facilitators than barriers to their consumption. Therefore, this data is relevant for the development of environmental interventions ${ }^{41}$.

Regarding the perception of the environment, we have identified a relationship between weight-status and the understanding of places that promote physical activity (e.g., squares, places for a walk, clubs, and soccer field). The inverse association between the prevalence of obesity and the presence of green areas, parks, and open spaces has been reported in the scientific literature $^{40,42}$.

In addition, to assisting in the mental restoration process, public parks and green areas can be places for the promotion of physical activity such as dance classes, aerobics, and running for the general public or specifics such as hypertensive, diabetic, or cardiopathy ${ }^{43,44}$. 
Table 3. Environment perception and scores, according to weight-status. Cohort of Universities of Minas Gerais (CUME project).

\begin{tabular}{|c|c|c|c|c|}
\hline & $\begin{array}{l}\text { Normal weight } \\
(\mathrm{n}=100) ; \mathrm{n}(\%)\end{array}$ & $\begin{array}{c}\text { Overweight } \\
(\mathbf{n}=38) ; \mathbf{n}(\%)\end{array}$ & $\begin{array}{c}\text { Total } \\
(\mathbf{n}=138) ; \mathbf{n}(\%)\end{array}$ & p-value \\
\hline Squares & & & & 0.038 \\
\hline$>10 \min ^{*}$ & $31(31.0)$ & $19(50.0)$ & $50(36.2)$ & \\
\hline Parks & & & & 0.736 \\
\hline$>10 \mathrm{~min}$ & $79(79.0)$ & $31(81.6)$ & $110(79.7)$ & \\
\hline Places for a walk & & & & 0.021 \\
\hline$>10 \mathrm{~min}$ & $52(52.0)$ & $28(73.7)$ & $80(58.0)$ & \\
\hline Open public spaces & & & & 0.008 \\
\hline$>10 \mathrm{~min}$ & $16(16.0)$ & $14.0(36.8)$ & $30(21.7)$ & \\
\hline Gyms & & & & 0.588 \\
\hline$>10 \mathrm{~min}$ & $14(14.0)$ & $4(10.5)$ & $18(13.0)$ & \\
\hline Clubs & & & & 0.040 \\
\hline$>10 \mathrm{~min}$ & $59(59.0)$ & $15(39.5)$ & $74(53.6)$ & \\
\hline Sports courts & & & & 0.754 \\
\hline$>10 \mathrm{~min}$ & $66(66.0)$ & $24(63.2)$ & $90(65.2)$ & \\
\hline Soccer fields & & & & 0.008 \\
\hline$>10 \min$ & $76(76.0)$ & $20(52.6)$ & $96(69.6)$ & \\
\hline Commercial PA establishments & & & & 0.984 \\
\hline$>10 \mathrm{~min}$ & $8(8.0)$ & $3(7.9)$ & $11(8.0)$ & \\
\hline Pharmacy & & & & 0.343 \\
\hline$>10 \mathrm{~min}$ & $10(10.0)$ & $6(15.8)$ & $16(11.6)$ & \\
\hline Hospitals and primary health units & & & & 0.614 \\
\hline$>10 \min$ & $40(40.0)$ & $17(44.7)$ & $57(41.3)$ & \\
\hline Mini-markets & & & & 0.415 \\
\hline$>10 \mathrm{~min}$ & $16(16.0)$ & $4(10.5)$ & $20(14.5)$ & \\
\hline Supermarket & & & & 0.548 \\
\hline$>10 \min$ & $34(34.0)$ & $15(39.5)$ & $49(35.5)$ & \\
\hline Churches or religious temples & & & & 0.552 \\
\hline$>10 \mathrm{~min}$ & $29(29.0)$ & $13(34.2)$ & $42(30.4)$ & \\
\hline Bus stop & & & & 0.125 \\
\hline$>10 \mathrm{~min}$ & $1(1.0)$ & $2(5.3)$ & $3(2.2)$ & \\
\hline Farmers Market & & & & 0.927 \\
\hline$>10 \mathrm{~min}$ & $64(64.0)$ & $24(63.2)$ & $88(63.8)$ & \\
\hline Bank branches & & & & 0.211 \\
\hline$>10 \min$ & $54(54.0)$ & $25(65.8)$ & $79(57.2)$ & \\
\hline Bars & & & & 0.853 \\
\hline$>10 \mathrm{~min}$ & $12(12.0)$ & $5(13.2)$ & $17(12.3)$ & \\
\hline Bakeries & & & & 0.354 \\
\hline$>10 \mathrm{~min}$ & $8(8.0)$ & $5(13.2)$ & $13(9.4)$ & \\
\hline Facilities/conveniences score ${ }^{\star *}$ & & & & 0.760 \\
\hline$<11$ & $45(45.0)$ & $16(42.1)$ & $61(44.2)$ & \\
\hline Social cohesion score ${ }^{\star *}$ & & & & 0.144 \\
\hline$<13$ & $44(44.0)$ & $22(58.9)$ & $66(47.8)$ & \\
\hline$\geq 13$ & $56(56.0)$ & $16(42.1)$ & $72(52.2)$ & \\
\hline Walking environment score ${ }^{\star *}$ & & & & 0.226 \\
\hline$<31$ & $51.0(51.0)$ & $15(39.5)$ & $66(47.8)$ & \\
\hline$\geq 31$ & $49.0(49.0)$ & $23(60.5)$ & $72(52.2)$ & \\
\hline
\end{tabular}


Table 3. Environment perception and scores, according to weight-status. Cohort of Universities of Minas Gerais (CUME project).

\begin{tabular}{|c|c|c|c|c|}
\hline & $\begin{array}{l}\text { Normal weight } \\
(\mathbf{n}=100) ; \mathbf{n}(\%)\end{array}$ & $\begin{array}{c}\text { Overweight } \\
(\mathbf{n}=38) ; \mathbf{n}(\%)\end{array}$ & $\begin{array}{c}\text { Total } \\
(\mathbf{n}=138) ; \mathbf{n}(\%)\end{array}$ & p-value \\
\hline Availability of healthy foods score ${ }^{* *}$ & & & & 0.703 \\
\hline$<6.5$ & $51(51.0)$ & $18(47.4)$ & $69(50.0)$ & \\
\hline$\geq 6.5$ & $49(49.0)$ & $20(52.6)$ & $69(50.0)$ & \\
\hline Safety score ${ }^{\star *}$ & & & & 0.924 \\
\hline$<9$ & $43(43.0)$ & $16(42.1)$ & $59(42.8)$ & \\
\hline$\geq 9$ & $57(57.0)$ & $22(57.9)$ & $79(57.2)$ & \\
\hline Perceived violence score ${ }^{\star \star}$ & & & & 0.761 \\
\hline$<17$ & $37(37.0)$ & $13(34.2)$ & $50(36.2)$ & \\
\hline$\geq 17$ & $63(63.0)$ & $25(65.8)$ & $88(63.8)$ & \\
\hline Personal victimization $^{\star \star}$ & & & & 0.226 \\
\hline 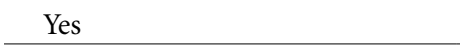 & $24(24.0)$ & $13(34.2)$ & $37(26.8)$ & \\
\hline
\end{tabular}

Poortinga (2006) evaluated adults in England and identified that the pleasant aspect of the open space was associated with positive self-reported health status and positive perception of access to leisure facilities, thus stimulating the practice of physical activity ${ }^{45}$.

It is important to note that the Scale of Perception of the Environment for the Practice of Physical Activity has been adapted from a globally-recognized scale that has the objective of assessing walkability and physical activity practice, but has been used with different health outcomes ${ }^{46,47}$. In Brazil, the EpiFloripa study evaluated the characteristics of the neighborhood environment and sedentary behavior in the elderly using the scale proposed by Florindo et al..$^{30}$. The authors identified that better access and greater diversity of places in the neighborhood environment (e.g., shops, services, food shops, access to bus stops, clubs and gyms, and open spaces gyms) could be an important factor to reduce sedentary behavior in older Brazilian adults ${ }^{48}$.

\section{Conclusions}

The results indicate the association between environmental characteristics and overweight in Brazilian adults. The most outstanding characteristics of the environment in this study were the location of commercial establishments for physical activity and food establishments. We also found a relationship between the outcome and the perception of the built environment related to the practice of physical activity such as sports courts, public open spaces, clubs and places for walking.

Given this, one must consider the environmental context where the individual is inserted so that effective and specific public policies can be developed in the region.

A limitation of this study is that all our participants are university graduates, and the generalizability of our findings to other groups with less education should not be assumed. However, this characteristic increases the quality of the self-reported information provided by participants. Further research should explore the associations found longitudinally.

\section{Collaborations}

ALG Domingos worked on research design, data analysis, and final drafting. HHM Hermsdorff worked on research design and critically reviewed the work. LL Mendes worked on research design, data analysis, and critically reviewed the work. FLP Oliveira worked on research design, data analysis, and critically reviewed the work. ACS Oliveira worked on data analysis and critically reviewed the work. AM Pimenta worked on research design and critically reviewed the work. J Bressan worked on research design, data analysis, and critically reviewed the work. 


\section{Acknowledgments}

We wish to express our gratitude to all the participants of The Cohort of Universities of Minas Gerais, without whom this study would not have been possible. A full list of participating CUME investigators and institutions can be found at www.projetocume.com.br. This research was made possible by funding received from the Minas Gerais Research Foundation - FAPEMIG (grants numbers: CDS-APQ-00571/13, CDSAPQ-02407/16, CDS - APQ-00424-17). J Bressan, HHM Hermsdorff, and FLP Oliveira are research productivity fellows of $\mathrm{CNPq}$ (Ministério da Ciência e Tecnologia, Brazil). This study was financed in part by the Coordenação de Aperfeiçoamento de Pessoal de Nivel Superior - Brasil (CAPES) - Finance Code 001. The funders had no role in the study design, data collection, and analysis, decision to publish, or preparation of the article.

\section{References}

1. World Health Organization (WHO). Obesity and overweight [Internet]. 2018. [cited 2018 Sep 28]. Available from: http://www.who.int/en/news-room/ fact-sheets/detail/obesity-and-overweight

2. Brasil. Ministério da Saúde (MS), Secretaria de Vigilância em Saúde Departamento de Vigilância de Doenças e Agravos não, Transmissíveis e Promoção da Saúde. Vigitel Brasil 2016: vigilância de fatores de risco e proteção para doenças crônicas por inquérito telefônico. Estimativas sobre frequência e distribuição sociodemográfica de fatores de risco e proteção para doenças crônicas nas capitais dos 26 estados brasileiro e no Distrito Federal em 2016. Brasília: MS; 2017.

3. Ghoorah K, Campbell P, Kent A, Maznyczka A, Kunadian V. Obesity and cardiovascular outcomes: a review. Eur Hear J Acute Cardiovasc Care. 2016;5(1):7785. doi:10.1177/2048872614523349

4. Garofalo C, Borrelli S, Minutolo R, Chiodini P, De Nicola L, Conte G. A systematic review and meta-analysis suggests obesity predicts onset of chronic kidney disease in the general population. Kidney Int 2017; 91(5):1224-1235.

5. Hruby A, Manson JE, Qi L, Malik VS, Rimm EB, Sun Q, Willett WC, Hu FB. Determinants and consequences of obesity. Am J Public Health 2016; 106(9):16561662.

6. Cawley J. An economy of scales: a selective review of obesity's economic causes, consequences, and solutions. J Health Econ 2015; 43:244-268.

7. Lehnert T, Sonntag D, Konnopka A, Riedel-Heller S, König HH. Economic costs of overweight and obesity. Best Pract Res Clin Endocrinol Metab 2013; 27(2):105115.

8. Swinburn B, Egger G, Raza F. Dissecting obesogenic environments: the development and application of a framework for identifying and prioritizing environmental interventions for obesity. Prev Med (Baltim) 1999; 29(6):563-570.

9. Doyle S, Kelly-Schwartz A, Schlossberg M, Stockard J. Active community environments and health: the relationship of walkable and safe communities to individual health. J Am Plan Assoc 2006; 72(1):19-31.

10. Fraser LK, Edwards KL, Tominitz M, Clarke GP, Hill AJ. Food outlet availability, deprivation and obesity in a multi-ethnic sample of pregnant women in Bradford, UK. Soc Sci Med 2012; 75(6):1048-1056.

11. Kamphuis CBM, Giskes K, de Bruijn G-J, Wendel-Vos W, Brug J, van Lenthe FJ. Environmental determinants of fruit and vegetable consumption among adults: a systematic review. Br J Nutr 2006; 96(4):620-635.

12. Li F, Harmer P, Cardinal BJ, Bosworth M, Johnson -Shelton D. Obesity and the built environment: does the density of neighborhood fast-food outlets matter? Am J Heal Promot 2009; 23(3):203-209.

13. Spence JC, Cutumisu N, Edwards J, Raine KD, Smoyer-Tomic K. Relation between local food environments and obesity among adults. BMC Public Health 2009; 9:6-11.

14. Fish JS, Ettner S, Ang A, Brown AF. Association of perceived neighborhood safety on body mass index. Am J Public Health 2010; 100(11):2296-2303. 
15. Fields R, Kaczynski AT, Bopp M, Fallon E. Built Environment Associations With Health Behaviors Among Hispanics. J Phys Act Heal 2013;10:335-342.

16. Domingos ALG, Miranda AEDS, Pimenta AM, Hermsdorff HHM, Oliveira FLP, Santos LC, Lopes ACS, Martínez-González MA, Bressan J. Cohort profile: the Cohort of Universities of Minas Gerais (CUME). Int J Epidemiol 2018; 47(6):1743-1744h.

17. Brasil. Ministério da Saúde (MS). Conselho Nacional de Saúde. Resolução n. 466 de 12 de Dezembro de 2012. Aprova as diretrizes e normas regulamentadoras de pesquisas envolvendo seres humanos. Brasilia: MS; 2012.

18. Instituto Brasileiro de Geografia e Estatística (IBGE). Cidades [Internet]. [cited 2017 Apr 20]. Available from: https://cidades.ibge.gov.br

19. Silva GM, Correia J, Menegatti RD, Fantini AC. Um retrato da evolução urbana de Viçosa-MG: impactos da federalização da UFV sobre a cidade (1969-2014). In: $2^{\circ}$ Seminário Nacional de Planejamento e Desenvolvimento; 2014:1-10.

20. Miranda AE S, Ferreira AVM, Oliveira FLP, Hermsdorff HHM, Bressan J, Pimenta AM. Validation of metabolic syndrome and its self reported components in the CUME Study. REME Rev Min Enferm. 2017; 21:e1069.

21. World Health Organization (WHO). Obesity: preventing and managing the global epidemic. Report of a WHO consultation. World Health Organ Tech Rep Ser 2000; 894:i-xii, 1-253.

22. National Institute on Alcohol Abuse and Alcoholism (NIAAA). Drinking Levels Defined [Internet]. [cited 2018 Apr 2]. Available from: https://www.niaaa.nih. gov/alcohol-health/overview-alcohol-consumption/ moderate-binge-drinking

23. Martinez-Gonzalez MA, Lopez-Fontana C, Varo JJ, Sanchez-Villegas A, Martinez JA. Validation of the Spanish version of the physical activity questionnaire used in the Nurses' Health Study and the Health Professionals' Follow-up Study. Public Heal Nutr 2005; 8(7):920-927.

24. World Health Organization (WHO). Global recommendations on physical activity for health. Geneva: WHO; 2010.

25. Day PL, Pearce J. Obesity-Promoting Food Environments and the Spatial Clustering of Food Outlets Around Schools. Am J Prev Med. 2011;40(2):113-121. doi:10.1016/j.amepre.2010.10.018

26. Austin SB, Melly SJ, Sanchez BN, Patel A, Buka S, Gortmaker SL. Clustering of fast-food restaurants around schools : a novel application of spatial statistics to the study of food environments. Am J Public Health 2005; 95(9):1575-1581.

27. Vegi LFM. Colet APP. 2016. Available from: https:// play.google.com/store/apps/details?id=lucas.vegi.coletapp\&hl=pt_BR

28. Secretaria-Executiva da Câmara Interministerial de Segurança Alimentar e Nutricional Ministério do Desenvolvimento Social (MDS). Mapeamento dos desertos alimentares no Brasil. Brasília: MDS; 2018.

29. Brasil. Decreto-Lei 2.848 , de 7 de dezembro de 1940 . Código Penal. Diário Oficial da União 1940, $31 \mathrm{dez}$.
30. Florindo AA, Guimarães VV, de Farias Júnior JC, Salvador EP, Sá TH, Reis RS, Hallal PC. Validation of the scale for evaluation of environment perception for physical activity practice in adults living in region of low socioeconomic level. Rev Bras Cineantropometria e Desempenho Hum 2012; 14(6):647-659.

31. Sampson RJ. Neighborhoods and violent crime: a multilevel study of collective efficacy. Science 1997; 277(5328):918-924.

32. Mujahid MS, Roux AVD, Morenoff JD, Raghunathan T. Assessing the measurement properties of neighborhood scales: from psychometrics to ecometrics. Am J Epidemiol 2007; 165(8):858-867.

33. Santos SM, Griep RH, Cardoso LO, Alves MG, Fonseca Mde J, Giatti L, Chor D. Cross-cultural adaptation and reliability of measurements on self-reported neighborhood characteristics in ELSA-Brasil. Rev Saude Publica. 2013; 47(Suppl. 2):122-130.

34. Alves NC. "Memória do Cantinho": formação da periferia urbana de Viçosa - MG. Rev Historia Contemp 2008; 2:1-15.

35. Paula KA. A produção do espaço urbano vertical na zona central de Viçosa-MG, no período 1980-2012. Viçosa: Universidade Federal de Viçosa; 2013.

36. Palladino R, Lee JT, Ashworth M, Triassi M, Millett C. Associations between multimorbidity, healthcare utilisation and health status: evidence from 16 European countries. Age Ageing 2016; 45(3):431-435.

37. Ministério da Saúde (MS). Secretaria de Vigilância em Saúde. VIGITEL 2016: vigilância de fatores de risco e proteção para doenças crônicas em inquérito telefônico. Brasília: MS; 2017.

38. Fátima L, Almeida F, Novaes TG, Pessoa C, Silva A, Mendes LL. Socioeconomic disparities in the community food environment of a medium-sized city of Brazil. J Am Coll Nutr 2020; 40(3):253-260.

39. Fortes MF, Borges CA, Miranda WC, Jaime PC. Mapeando as desigualdades socioeconômicas na distribuição do comércio varejista local. Segurança Aliment e Nutr 2018; 25(3):45-58.

40. Jaime PC, Duran AC, Sarti FM, Lock K. Investigating environmental determinants of diet, physical activity, and overweight among adults in Sao Paulo, Brazil. J Urban Health 2011; 88(3):567-581.

41. Almeida LB, Scagliusi FB, Duran AC, Jaime PC. Barriers to and facilitators of ultra-processed food consumption: perceptions of Brazilian adults. Public Health Nutr 2018; 21(1):68-76.

42. Wen M, Kowaleski-Jones L. The built environment and risk of obesity in the United States: Racial-ethnic disparities. Health Place 2012; 18(6):1314-1322.

43. Parra DC, McKenzie TL, Ribeiro IC, Ferreira Hino AA, Dreisinger M, Coniglio K, Munk M, Brownson RC, Pratt M, Hoehner CM, Simoes EJ. Assessing physical activity in public parks in Brazil using systematic observation. Am J Public Health 2010; 100(8):14201426.

44. Paquet C, Coffee NT, Haren MT, Howard NJ, Adams RJ, Taylor AW, Daniel M. Food environment, walkability, and public open spaces are associated with incident development of cardio-metabolic risk factors in 
a biomedical cohort. Health Place 2014; 28:173-176.

45. Poortinga W. Perceptions of the environment, physical activity, and obesity. Soc Sci Med 2006; 63(11):28352846.

46. Malambo P, Kengne AP, Lambert EV, Villiers A, Puoane $T$. Does physical activity mediate the association between perceived neighborhood aesthetics and overweight/obesity among South African adults living in selected urban and rural communities? J Phys Act Heal 2017; 14(12):925-932.

47. Gebel K, Bauman AE, Sugiyama T, Owen N. Mismatch between perceived and objectively assessed neighborhood walkability attributes: prospective relationships with walking and weight gain. Health Place 2011; 17(2):519-524.

48. Arins GCB, Santos CE, Giehl MWC, Benedetti TRB, Oliveira C, D’Orsi E, Rech CR. Neighborhood environmental characteristics and sedentary behavior in later life: the EpiFloripa Study. Rev Bras Atividade Fiísica e Saúde 2018; 23:e0007.

Article submitted 28/09/2020

Approved 15/03/2021

Final version submitted 17/03/2021

Chief editors: Romeu Gomes, Antônio Augusto Moura da Silva 